\title{
In Vitro and In Vivo Antibacterial Activity of Some Organic and Inorganic Salts Against Asiatic Citrus Canker Agent Xanthomonas Citri Subsp. Citri
}

\author{
Vahideh Hasabi $^{1,3}$, Hossein Askari ${ }^{12^{*}}$, Seyed Mehdi Alavi ${ }^{2}$, Masood Soltani Najafabadi ${ }^{4}$ \\ I*Department of Biotechnology, Faculty of New Technologies and Energy Engineering, Shahid Beheshti University, G.C., Evin, Tehran, \\ Iran. \\ ${ }^{2}$ Department of Plant Biotechnology, National Institute for Genetic Engineering and Biotechnology (NIGEB), P. O. Box:14155-6343, \\ Tehran, Iran. \\ ${ }^{3}$ Department of Plant Protection, College of Agriculture and Natural Resources, Science and Research Branch, Islamic Azad University \\ (IAU), P.O. Box 14515-775, Tehran, Iran. \\ ${ }^{4}$ Oil Seeds Research Department, Seed and Plant Improvement Institute (SPII), Karaj, Iran
}

\section{A R T I C LE IN F O}

\section{Article history:}

Received 05 May 2014

Accepted 26 June 2014

Available online, ISSN: 2148-127X

\section{Keywords:}

Xanthomonas citri subsp. Citri

Bacterial citrus canker disease

Antibacterial activity

Salt

Lime
A B S T R A C T

Asiatic citrus canker caused by Xanthomonas citri subsp. citri is becoming a disease of high economic impact, affecting all types of important citrus crops. In this study, the potential antibacterial activity of ten organic and inorganic salts on X. citri subsp. citri and on citrus canker disease development was evaluated. Among the salt compounds, copper, iron and zinc inorganic salts particularly zinc (with the highest diameter of inhibition, the lowest MIC and MBC values and the highest bacterial growth inhibitory effect) had direct antibacterial activity and strongly reduced the development of canker disease and bacterial population of lime plants.

\section{Introduction}

Asiatic citrus canker (ACC) is one of the most feared of citrus diseases, affecting all types of important citrus crops. The disease causes extensive damage to citrus and severity of this infection varies with different species and varieties and the prevailing climatic conditions. The disease caused by Xanthomonas citri subsp. citri (syn. X. citri pv. citri Gabriel et al., 1989), characterized by the occurrence of conspicuous raised necrotic lesions that develop on leaves, twigs and fruits. Severe infections can cause a range of symptoms from defoliation, blemished fruit, premature fruit drop, and twig dieback to general tree decline (Francis et al., 2009; Dewdney and Graham, 2012). The disease is endemic in India, Japan and other South- East Asian countries, from where it has spread to all other citrus producing continents (Dewdney and Graham, 2012). There are no highly effective canker disease suppression strategies for the most susceptible cultivars of citrus. Copper reduces bacterial populations on leaf surfaces, but the long-term use of copper bactericides induce copper resistance in xanthomonad populations and accumulation of copper in citrus soils have potential phytotoxic and adverse environmental effects. However, other contact bactericides are not as effective as copper because they lack sufficient residual activity to protect leaf and fruit surfaces for extended periods (Graham et al. 2000), so the develop of more effective alternative compounds to control citrus canker is crucial. Application of organic and inorganic salts, Generally Recognized as Safe (GRAS) compounds, is an interesting alternative to control plant diseases (Talibi et al., 2011). Moreover, these compounds have a broadspectrum antimicrobial activity (Deliopoulos et al., 2010). Recent reports have indicated that certain organic and inorganic salts inhibit the growth of many pathogens (Mimee et al., 2011; Talibi et al., 2011; Avis et al., 2009). The present study was performed to evaluate the efficacy of some organic and inorganic salts for in vitro and in vivo control of $X$. citri subsp. citri, the causal agent of citrus canker disease. 


\section{Materials and Methods}

\section{Plant Materials}

Two years old lime seedlings were used as plant material. They were maintained at $25-30^{\circ} \mathrm{C}$ and $60 \%$ relative humidity conditions in a greenhouse.

\section{Bacterial Culture}

Bacterial inoculum was prepared with Xcc strain 88 obtained from National Institute of Genetic Engineering and Biotechnology (NIGEB). The bacterial strain was maintained by serial transfer on Nutrient Agar (NA) (Merck) and periodically reisolated from inoculations described below to maintain virulence. For greenhouse tests, the strain was grown in nutrient broth and incubated on a shaker at $28^{\circ} \mathrm{C}$ for $24 \mathrm{~h}$.

\section{Salt Compounds}

A total of ten salt compounds (Table 1) were used in this study (Merck Millipore, Germany) to evaluate their effectiveness against Xcc. Stock solutions of each reagent were prepared at a concentration of $500 \mathrm{mM}$ and sterilized by filtering through a sterile $0.20 \mu \mathrm{m}$ Minisart filter.

Table 1 Salt compounds tested to evaluate their effectiveness against Xanthomonas citri subsp. citri

\begin{tabular}{l|cc}
\hline \multicolumn{1}{c|}{ Compounds } & $\begin{array}{c}\text { Chemical } \\
\text { formula }\end{array}$ & $\begin{array}{c}\text { Effectiveness } \\
\text { against Xcc }\end{array}$ \\
\hline Copper (II) sulfate & $\mathrm{CuSO}_{4}$ & + \\
ferrous sulfate & $\mathrm{FeSO}_{4} \cdot 7 \mathrm{H}_{2} \mathrm{O}$ & + \\
Potassium bicarbonate & $\mathrm{KHCO}_{3}$ & - \\
Potassium carbonate & $\mathrm{K}_{2} \mathrm{CO}_{3}$ & - \\
Potassium sorbate & $\mathrm{C}_{6} \mathrm{H}_{7} \mathrm{KO}_{2}$ & - \\
Potassium formate & $\mathrm{CHKO}_{2}$ & - \\
Sodium carbonate & $\mathrm{Na}_{2} \mathrm{CO}_{3}$ & - \\
Sodium bicarbonate & $\mathrm{NaHCO}_{3}$ & - \\
Sodium benzoate & $\mathrm{NaC}_{7} \mathrm{H}_{5} \mathrm{O}_{2}$ & - \\
Zinc sulfate & $\mathrm{ZnSO}_{4} \cdot 7 \mathrm{H}_{2} \mathrm{O}$ & + \\
\hline
\end{tabular}

\section{Inhibitory Effect of Salt Solutions on Xcc In Vitro}

\section{Antibacterial screening}

To determine direct antimicrobial activity of the salt compounds on $X c c$, the disc diffusion method was used (Bauer et al., 1966). In this case, $100 \mu$ l of each bacterial suspension was spread evenly over NA plates with sterile glass rods and allowed to dry. Analytical blank paper dicks with 6.4 diameter (PATAN TEB company, Iran) dipped with $50 \mu \mathrm{l}$ of each compound at the concentrations of 50 and $100 \mathrm{mM}$ and distilled water as control, were placed on the surface of medium and tapped likely to ensure even contact. All plates were incubated at $28^{\circ} \mathrm{C}$ for 24 hours. Each experiment was carried out in triplicates, and the antibacterial activity was determined by measuring the diameter of zone of inhibition in $\mathrm{mm}$.

\section{Determination of $M I C$ and $M B C$}

The minimum inhibitory concentration (MIC) of the salt treatments had direct antibacterial activity against $X c c$, was determined by serial dilution technique (Jawetz et al., 1980) from a concentration of 0.1 to $200 \mathrm{mM}$ in total volume of $200 \mu \mathrm{l}$ with $0.1 \mathrm{mM}$ as interval against $X c c$ strain. Bacterial suspension $(100 \mu \mathrm{l})$ containing $10^{6-}$
$10^{8} \mathrm{CFU} \mathrm{ml} \mathrm{m}^{-1}$ was inoculated into a sterile 96 wells plate (GRE 961) and was incubated at $28^{\circ} \mathrm{C}$ and observed for bacterial growth during 24 hours. After incubation, the samples with no visible growth of the bacterium in comparison to the control (bacterial suspension without any treatment) were taken to represent the minimum bactericidal concentration (MBC) value of the given salt treatments in $\mathrm{mM}$.

Effect of salt solutions on canker disease development

Based on the in vitro antibacterial activity, only salt compounds with direct activity were retained. The inhibitory effect of salt solutions on the development of canker disease on lime leaves was determined following a single foliar spray of each solution. Fresh solutions of 10 $\mathrm{mM} \mathrm{CuSO} 4, \mathrm{FeSO}_{4}$ and $\mathrm{ZnSO}_{4}$ were prepared and sprayed on the upper surface of each of lime plants as prophylactic treatment. Control plants were sprayed with water. Plants were kept in the greenhouse and 48 hours after treatment, three plants per treatment were inoculated with Xcc and distilled water as control Bacterial suspension was centrifuged at $10,000 \mathrm{~g}$ for $20 \mathrm{~min}$, and adjusted to $0.4 \mathrm{OD}$ at $\mathrm{A}_{600} \mathrm{~nm}$ equivalent to $10^{8}$ colonyforming units (CFU) $\mathrm{ml}^{-1}$. Immature leaves $(75 \%$ expanded) were inoculated using a tuberculin syringe (1.0 $\mathrm{cm}^{3}$ ) with no needle. Xcc inoculum was infiltrated by pressing the needleless syringe tip against the abaxial leaf surface to produce a zone of water-soaked tissue $2 \mathrm{~mm}$ beyond the diameter of the syringe opening. The infiltrated area of the leaf was approximately $6 \mathrm{~mm}$ diameter and contained an estimated $2 \mu \mathrm{l}$ of bacterial suspension. Three injection infiltrations were performed on each side of the mid-vein. Ten leaves were inoculated per plant. The inoculated shoots were covered with plastic bags for 1 day to maintain high humidity conducive for bacterial growth in the leaves. A completely randomized experimental design including three replicates was used. Development of canker disease was determined at each infected leaf 1, 7, 14, 21, 28 and 35 days after inoculation, by measuring the bacterial population. The bacterial population was determined by macerating $0.64 \mathrm{~cm}^{2}$ of inoculated leaf area in $1 \mathrm{ml}$ distilled water by plating on to Nutrient agar. The Petri plates were evaluated after 48 hours of incubation at $28^{\circ} \mathrm{C}$. The bacterial population was expressed on $\log$ CFU (colony-forming units) $/ 0.64 \mathrm{~cm}^{2}$ of leaf tissue.

\section{Data Analysis}

Analysis of variance was carried out with the GLM procedure of SAS (SAS Institute, Cary, NC). When significant $(P<0.05)$, treatment means were compared using Duncan's protected least significant difference.

\section{Results}

\section{Inhibitory Effect of Salt Solutions on Xcc In Vitro}

\section{Antibacterial screening}

Analysis of antibacterial activity of selected concentrations of salt treatments showed that $\mathrm{Cu}, \mathrm{Fe}$ and $\mathrm{Zn}$ salts have a direct antibacterial activity against $X c c$ strain in concentrations of 50 and $100 \mathrm{mM}$. In contrast, other tested salts have no direct inhibitory effect against the representative strain of Iranian $X c c$ even in a high concentration $(500 \mathrm{mM})$. There was a significant 
difference in diameter of inhibition zone between $\mathrm{Zn}$ with $\mathrm{Cu}$ and $\mathrm{Fe}$ compounds (Fig. 1). The diameters of inhibition of $50 \mathrm{mM} \mathrm{Cu}, \mathrm{Fe}$ and $\mathrm{Zn}$ were in a range of 14.3, 15.4 and $24.3 \mathrm{~mm}$ respectively. As a consequent, among tested compounds, $\mathrm{Zn}$ caused the largest zone of inhibition against $X c c$ strain.

\section{Determination of $M I C$ and $M B C$}

The differences between the MIC and MBC values calculated for $\mathrm{Cu}, \mathrm{Fe}$ and $\mathrm{Zn}$ were found to be statistically significant $(\mathrm{P}<0.05)$. Among the salt compounds, $\mathrm{Zn}$ showed the lowest MIC (1.25 mM) and MBC (2.5 mM) (Fig. 2).

\section{Effect of Salt Solutions on Canker Disease Development}

The effect of salt compounds on disease development was determined by a single foliar spray of each compound on leaves 48 hours after inoculation with $X c c$ suspension. Our results showed that spray with $\mathrm{Zn}$ and $\mathrm{Fe}$ like $\mathrm{Cu}$ salts reduce bacterial population in lime plants about $71 \%$ as compared to the untreated check treatment (Fig. 3).

\section{Discussion}

$X$. citri subsp. citri is the causal agent of Asiatic citrus canker disease making economical damages to many citrus species and Rotaceous plants (Graham et al., 2000; Dewdney and Graham, 2012). No highly effective strategy has so far been presented to control the disease. The antibacterial activity of copper-based bactericides has been drawn attention of many investigators (Graham et al., 2000), but the emergence of copper resistant strains in the genus Xanthomonas make necessities towards developing more effective strategies to combat the disease (Rialdi et al., 2000). Several reports show that salt compounds have a broad- spectrum antimicrobial activity (Deliopoulos et al., 2010). Furthermore, Many of these salts have several advantages such as low mammalian toxicity, favorable safety profile for humans and environment and a relatively low cost (Olivier et al., 1998; Hervieux et al., 2002; Deliopoulos et al., 2010). The present study focused on an attempt to investigate the potential bactericidal effect of ten organic and inorganic salts on $X c c$. The data provided by this study showed that in addition to copper, inorganic salts such as iron and zinc, have also an in vitro and in vivo antibacterial activity against Xcc. These compounds inhibited the growth of targeted $X c c$ strain and have been shown to be toxic at minimum concentrations of $2.5,1.25$ and $5 \mathrm{mM}$, respectively. The highest susceptibility of the strains was observed in response to $\mathrm{Zn}$ with inhibitory zones of 24.3 mm.

The antimicrobial activity of metal (II) complexes such as copper (II), zinc (II) and iron (II) (Osowole et al., 2012; Sharma et al., 2011; Chohan et al., 2006) against the vast range of pathogens such as bacteria and fungi has been recognized for a long time (Elsome et al., 1996; Osowole et al., 2012; Sharma et al., 2011). It was demonstrated that conidial germination and development of Helminthosporium solani could completely be inhibited by Iron salts (Mimee et al., 2011). Iron could also control or reduce the severity of several diseases such as rust in wheat leaves, smut in wheat and Colletotrichum musae in banana (Graham and Gottwald, 1991).

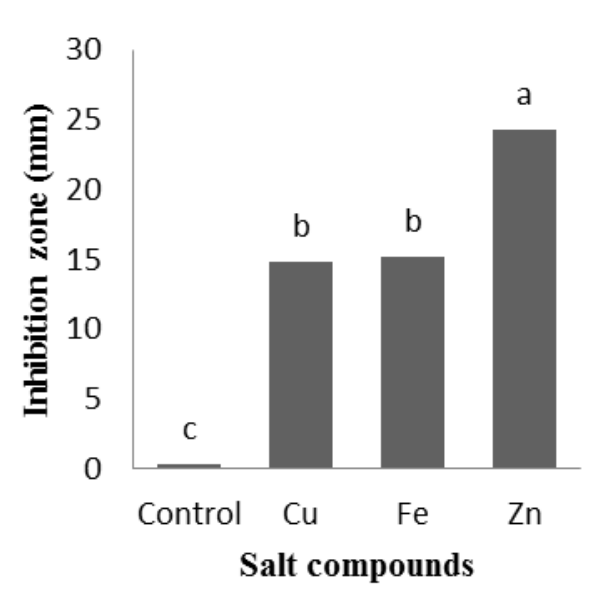

Fig. 1 The comparison between inhibition zone caused by $\mathrm{Cu}$, $\mathrm{Fe}$ and $\mathrm{Zn}$ salts against Xanthomonas citri subsp. citri. Values with different letters are significantly different according to Duncan $(p=0.05)$ test. The inhibition zones caused by $\mathrm{Zn}$ were mostly larger than those of other compound examined

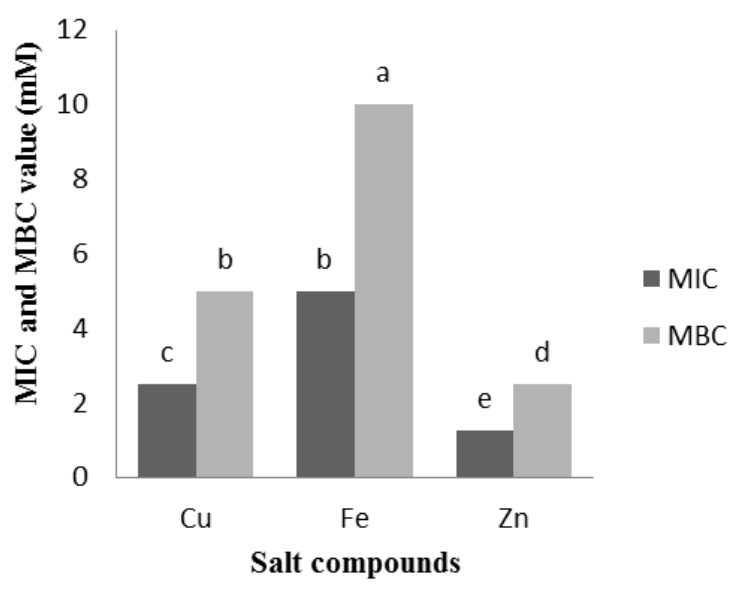

Fig. 2 MIC and MBC values of $\mathrm{Cu}, \mathrm{Fe}$ and $\mathrm{Zn}$ salt compounds on Xanthomonas citri subsp. citri strain. Values with different letters are significantly different according to Duncan $(p=0.05)$ test. $\mathrm{Zn}$ compound had the lowest MIC and MBC values respectively

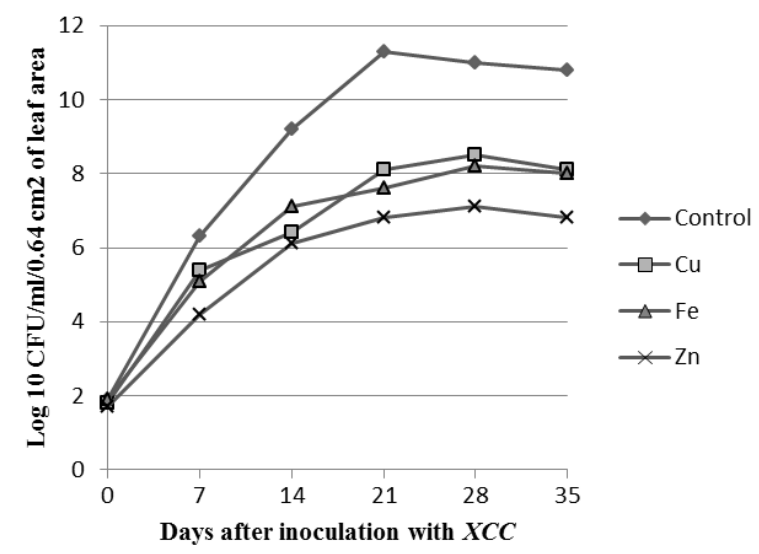

Fig. 3 Colony-forming unit of Xanthomonas citri subsp.citri on leaves of lime plants treated with distilled water (control), $\mathrm{Cu}$, Fe and $\mathrm{Zn} \mathrm{0,} \mathrm{7,} \mathrm{14,} \mathrm{21,} 28$ and 35 days after inoculation with bacterial suspension. 
Zinc was also found to have a toxic effect on the pathogen directly (Graham and Gottwald, 1991). Application of $\mathrm{Zn}$ reduced infections caused by Fusarium graminearum and root rot diseases caused by Gaeumanomyces graminis in wheat (Graham et al. 1991; Grewal et al., 1996). The antibacterial effect of zinc on Staphylococcus auerus and Pseudomonas aeruginosa was described by Atmaca et al., 1998. Zinc ion concentrations of $10^{-5}-10^{-7} \mathrm{M}$ are required for in vitro optimal growth of most microorganisms (Sugarman et al., 1983). However, it is claimed that high zinc ion concentrations may have some antibacterial properties (Liedtke et al., 2012). From several possible mechanisms for zinc antibacterial action, the ability to bind to the cell membrane has been highlighted (Sugarman et al., 1983). Zinc prolongs the lag phase of the growth cycle and increases the generation time of the microbes so that it takes each organism more time to complete cell division (Radke et al., 1994). Along with zinc, antimicrobial mechanisms of $\mathrm{Cu}$ are very complex. Some reports suggested that the 3-dimensional structure of proteins can be altered by copper, so that the proteins can no longer perform their normal functions. The result is inactivation of the pathogen. Also copper complexes can form radicals that inactivate viruses (Vasudevachari and Antony, 1982). Copper may also disrupt enzyme structures and functions by binding to sulfur or carboxylate containing groups and amino groups holes in the cell membranes, thereby compromising the integrity of cells of proteins and can interact with lipids, causing their peroxidation and opening holes in the cell membranes, thereby compromising the integrity of cells. This can cause leakage of essential solutes, which in turn, can have a desiccating effect (Manzl et al., 2004). Copper damages the respiratory chain in Escherichia coli cells and is associated with impaired cellular metabolism (Domek et al., 1987).

In conclusion, this study is a part of an overall study that aims to determine the antibacterial activity of salt compounds, against citrus canker disease. Among the ten compounds tested $\mathrm{Fe}, \mathrm{Cu}$ and $\mathrm{Zn}$ salt compounds particularly $\mathrm{Zn}$ (with the highest diameter of inhibition the lowest MIC and MBC values and the highest bacterial growth inhibitory effect) strongly decreased the canker disease damaged by $X$. citri subsp. citri.

\section{Acknowledgement}

The present work was a part of grant no. M-406 supported by National Institute of Genetic Engineering and Biotechnology (NIGEB), Iran.

\section{References}

Atmaca S, Gul G, Cicek R. 1998. The Effect of Zinc On Microbial Growth. Tr. J. MED. SCI. 28: 595-597.

Avis TJ, Rioux D, Simard M, Michaud M, Tweddell RJ. 2009. Ultrastructural alterations in Fusariumsam sambucinum and Heterobasidion annosum treated with aluminum chloride and sodium metabisulfite. Phytopathol. 99:167-175

Bauer AW, Kirby WM, Cherris JC, Truck M. 1966. Antibiotic susceptibility testing by a standardized single disk method. Am. J. Clin. Pathol. 45: 493-496.
Chohan Z.H, Arif M, Akhtar MA, Supuran CT. 2006. MetalBased Antibacterial and Antifungal Agents: Synthesis, Characterization, and In Vitro Biological Evaluation of $\mathrm{Co}(\mathrm{II}), \mathrm{Cu}(\mathrm{II}), \mathrm{Ni}(\mathrm{II})$, and $\mathrm{Zn}(\mathrm{II})$ Complexes With Amino Acid-Derived Compounds. Bioinorg. Chem. Appl. 1-13.

Deliopolous T, Kettlewell PS, Hare MC. 2010. Potential management of fungal potato disease using inorganic salts. Proceedings Crop protection in Northern Britain. 237-240.

Dewdney MM, Graham JH. 2012. Florida Citrus Pest Management Guide: Citrus Canker. university of florida. 182-186.

Domek MJ, Robbins JE, Anderson ME, McFeters GA. 1987. Metabolism of Escherichia coli injured by copper. Can. J. Microbiol. 33: 57-62.

Elsome AM, Jeremey MT, Miller H, Bmmfitt W, Noble WC. 1996. Antimicrobial activities in vitro and in vivo of transition element complexes containing gold (I) and osmium (VI). J. Antimicrob. Chemoth. 37: 911-918.

Francis MI, Redondo A, Burns JK, Graham JH, 2009. Soil application of imidacloprid and related SAR-inducing compounds produces effective and persistent control of citrus canker. Eur. J. Plant Pathol. 124: 283-292.

Gabriel DW, Kingsley MT, Hunter JE, Gottwald TR. 1989. Reinstatement of Xanthomonas citri (ex Hasse) and X. phaseoli (ex Smith) and reclassification of all X. campestris pv.citri strains. Int. J. Syst. Bacteriol. 39: 14-22.

Graham JH, Gottwald TR, Riley TD, Cubero J, Drouillard DL. 2000. Survival of Xanthomonas campestris pv.citri (Xcc) on various surfaces and chemical control of Asiatic citrus canker (ACC). Proc. Intn. Citrus canker Res. Workshop. June 20-22, 2000, Ft. Pierce, Florida, p.7.

Graham JH, Gottwald TR. 1991. Research perspectives on eradication of citrus bacterial canker disease in Florida. Plant Dis. 75: 1193-1200.

Grewal HS, Graham RD, Rengel Z. 1996. Genotypic variationin zinc efficiency and resistance to crown rot disease (Fusarium graminearumSchw. Group 1) in wheat. Plant Soil. 186: 219-226.

Hervieux V, Yaganza ES, Arul J, Tweddell RJ. 2002. Effect of organic and inorganic salts on the development of Helminthosporium solani, the causal agent of potato silver scurf. Plant Dis. 86:1014-1018.

Jawetz E, Melnick JL, Adelberg EA. 1980. Review of Medical Microbilogy.Lange, Medical pub. 14th ed., California 123124.

Kuwahara J, Suzuki T, Funakoshi K, Sugiura Y. 1986. Photosensitive DNA cleavage and phage inactivation by copper(II)-camptothecin. Biochem. 25: 1216-21.

Manzl C, Enrich J, Ebner H, Dallinger R, Krumschnabel G. 2004. Copper-induced formation of reactive oxygen species causes cell death and disruption of calcium homeostasis in trout hepatocytes. Toxicol. 196: 57-64.

Mimee B, Avis TJ, Boivin S, Jabaji S, Tweddell RJ. 2011. Effect of iron and nitrogen on the development of Helminthosporium solani and potato silver scurf. Can. J Plant Pathol. 33: 506-511.

Olivier C, Halseth DE, Mizubuti ESG, Loria R. 1998. Postharvest application of organic and inorganic salts for suppression of silver scurf on potato tubers. Plant Dis., 82: 213-217.

Osowole AA, Balogun SA. 2012. Spectral, Magnetic, Thermal and Antibacterial Properties of Some Metal (II) Complexes of Aminoindanyl Schiff Base. Eur J Appl Sci. 4: 06-13.

Radke LL, Hahn BL, Wagner DK, Sohnle PG. 1994. Effect of abscess fluid supernatant on kinetics of Candida albicans growth. Clinical Immun. And Immuno. Pathol. 73: 344-9.

Rinaldi DAMF, Leite RPJr. 2000. Adaptation of Xanthomonas axonopodis pv. citri population to the presence of copper compounds in nature. Proc. Int. Soc. Citric. 2, 1064. 
Sharma S, Ramani J, Bhalodia J, Patel N, Thakkar K, Patel R. 2011. Synthesis, Characterization and Antimicrobial Activity of Some Transition Metal Complexes (Mn, Co, Zn, Ni) With L-Proline and Kojic Acid. Adv. Appl. Sci. Res. 2: 374-382.

Sugarman B. 1983. Zinc Infection. Rev. Inf. Dis. 138-147.

Talibi I, Askarne L, Boubaker H, Boudyach EH, Aoumar AB.
2011. In vitro and In vivo Antifungal Activities of Organic and Inorganic Salts Against Citrus Sour Rot Agent Geotrichum candidum. Plant Pathol. J. 10: 138-145.

Vasudevachari M, Antony A. 1982. Inhibition of avian myeloblastosis virus reverse transcriptase and virus inactivation by metal complexes of isonicotinic acid hydrazide. Ant. Res. 2: 291-300. 